\title{
Age trends in genetic parameters for growth and quality traits in Abies alba
}

Georgeta Mihai, lonel Mirancea

\section{Introduction}

European silver fir (Abies alba Mill.) is one of the most important forest species in Romania, both for economic and ecological purposes. It covers about $5 \%$ of the national forest area (approximately 292,000 ha), ranking second after Norway spruce among coniferous species (NFI 2012). Silver fir grows in mixed mountain forests along with European beech (Fagus sylvatica L.) Norway spruce (Picea abies (L.) Karst.) and other deciduous species. Its natural range in Romania is discontinuous, reaching the maximal spread in the Eastern Carpathians, while it shows a very fragmented distribution in the Southern Carpathians, Apuseni and Maramures Mountains. Silver fir tim ber has multiple uses, such as construction wood, furniture, plywood, pulpwood, etc. Also, through a very deep rooting system, it contributes to the stability of mountain ecosystems against windfall, especially in pure spruce stands.

"Marin Dracea" National Institute for Research and Development in Forestry, Department of Forest Genetics and Tree Breeding, B-dul Eroilor 128, 077190 Voluntari (Romania)

@ Georgeta Mihai (gmihai_2008@yahoo.com)

Received: Jul 13, 2015 - Accepted: Apr 04, 2016

Citation: Mihai G, Mirancea I (2016). Age trends in genetic parameters for growth and quality traits in Abies alba. iForest 9: 954-959. - doi: 10.3832/ifor1766-009 [online 2016-07-07]

Communicated by: Fikret Isik Progeny Trial, Silver Fir
The first breeding programme of European silver fir in Romania started in the 1980 s at the Forest Research and Management Institute by establishing 12 seed orchards and 10 provenance trials, with 33 autochthonous and 27 foreign provenances, and 1 progeny trial. The next experiment series were initiated in 2007-2008, comprising five full-sib trials generated by control pollination in seed orchards, and in 2010, comprising two nursery tests with open-pollinated progeny (Mihai et al. 2014). The results of the first experiment series were published by Damian \& Leandru (1984), Deaconu (1991), Mihai et al. (2007), Mihai (2009) and have focused mainly on inter-population variation and selection of the best seed sources. Regarding intra-population genetic variation and genetic parameters estimates, the only data published were based on assessments at the age of 25 years (Mihai et al. 2007). Therefore, there are no comprehensive

\begin{abstract}
Genetic parameters for growth, stem straightness, survival, wood density and percentage of late wood were estimated in a progeny test of European silver fir (Abies alba Mill.) established in Romania in 1980. The experiment was conducted on 95 families collected from 10 natural stands and five provenance regions, and trait measurements were taken 6-34 years after planting. The family effect was highly significant for $\mathbf{1 4}$ traits and significant for one trait. The additive genetic variance increased with age for all the studied traits, and family heritability was higher than individual heritability. Stem diameter, volume per tree, wood density and late wood were the traits with the highest heritability. The trend of individual and half-sib family heritability estimates decreased between 6 and 15 years of age for height and between 6 and 10 years for diameter, while both height and diameter heritabilities were stable at older ages. High age-age genetic correlations were observed, though genetic correlations between growth and wood density were weak. Selection at age 6-10 could increase genetic gain in volume in mature silver fir trees. Selection based on family breeding values combined with within-family selection is recommended to maximize genetic gain in breeding activities in silver fir.
\end{abstract}

Keywords: Age-age Correlations, Genetic Gain, Heritability, Optimum Age,

analysis of the inter-individual variability and the time trend of genetic parameters of silver fir in Romania.

The success of a breeding strategy for any species depends on reliable information of the genetic parameters and pattern of variation of characters for which selection will be made (Namkoong 1979). Thus, the more accurate estimates of genetic parameters are the more realistic predictions of times and costs involved in a breeding programme will be. Moreover, the choice of traits and the optimum age for selection are crucial for the long-term efficiency of breeding programmes (Zobel \& Talbert 1984). In general, growth, stem straightness and wood quality had the highest priority in most breeding programmes of forest tree species (Dieters 1996, Haapanen et al. 1997, Dean \& Stonecypher 2006 , Stoehr et al. 2008, Stackpole et al. 2010, Ye \& Jayawickrama 2012).

Most breeding programmes involves tree selection at juvenile age. The time trend of genetic parameters is essential to determine the optimal selection age (Hodge \& White 1992). Early selection of juvenile trees can reduce the generation time and increase the gain per year. However, too early selection may lead to poor and unreliable estimates of the gain expected in terms of mature performances of trees (Dean \& Stonecypher 2006). Also, genetic and phenotypic relationships among different traits or ages of measurement are used to develop selection indices, to maximize the genetic gain and to evaluate efficiency 
of selection.

Despite the economic importance of silver fir, little data have been published regarding genetic parameters of its traits (Zobel \& Jett 1995, Ballian 2000, Gagov et al. 2005, Mihai et al. 2007, Barzdajn 2010, Mihai et al. 2014). Most of the studies presented results from provenance trials (Mayer et al. 1980, Gagov 1985, Ducci 1991, Kranenborg 1994, Wolf 1994, Hansen \& Larsen 2004, Kerr et al. 2015). Although a number of studies in the literature have documented the time trends of genetic parameters in tree species such as Scots pine (Jansson et al. 2003), Norway spruce (Huhn \& Kleinschmit 1993), loblolly pine (Svensson et al. 1999), no such data are available so far for European silver fir.

To address these problems, the objectives of this paper are: (1) to evaluate the variability and estimate the variance components and heritability for growth, wood quality traits and survival at ages 34 years in the progeny trial from the above-mentioned first experiment series; (2) to estimate the trait-trait and age-age genetic correlations; (3) to assess the early selection efficiency and determine the optimum age of selection; and (4) to estimate the genetic gains. The results will be discussed in relation to their implications and genetic strategies for future breeding activities of silver fir.

\section{Materials and methods}

\section{Genetic material, experimental design} and measurements

Progeny from 95 open-pollinated silver fir trees were tested in a half-sib trial established in 1980 in the Sacele Forest District (central Romania). Mother trees were selected from 10 natural stands and five provenance regions (Fig. 1). The trial is situ- ated in the deciduous and coniferous mixed layer at $45^{\circ} 48^{\prime} \mathrm{N}$ latitude, $25^{\circ} 72^{\prime} \mathrm{E}$ longitude and elevation of $1225 \mathrm{~m}$ a.s.l.

The experimental design of the progeny test was a randomized complete block design. Each of the 10 provenances was represented by 10 families with five seedlings per plot, in four blocks. Out of the original 100 half-sib families, 95 have survived and were included in this study. All measurements were carried out accordingly with the IUFRO methodology. The traits analyzed were: height (in meters) at ages 6,10 , 15, 25 and 34 years (HT6, HT10, HT15, HT25, HT34, respectively); root collar diameter $(\mathrm{cm})$ at ages 6, 10 and 15 years (DRC6, DRC10, DRC15); diameter at $1.30 \mathrm{~m}$ above the ground (in $\mathrm{cm}$ ) at ages 25 and 34 years (DBH25, DBH34); volume $\left(\mathrm{dm}^{3}\right)$ at age 34 years (VOL34); stem straightness (STR34); wood density (DENS34) in $\mathrm{g} / \mathrm{cm}^{3}$; percentage of late wood (LW34); and survival (\%) at age 34 years (SURV 34). Stem straightness was assessed on a 1-3 scale (1= straight; 2 = slightly curved; 3 = sinuous). The density was determined on wood samples extracted by a Pressler drill at $1.30 \mathrm{~m}$ of height following the formula reported by Dumitriu-Tataranu et al. (1983). Late wood was measured using the Lintab ${ }^{\circledR}$ equipment (RinnTech e.K., Heidelberg, Germany) and the software package TSAPWin ${ }^{\circledast}$ ver. 0.53 (RinnTech), with an accuracy of $0.001 \mathrm{~mm}$.

\section{Statistical analysis}

For each trait, the linear mixed model included random effects for provenance, family, family $\times$ block and within-plot as well as fixed effects for blocks. The variance components were estimated using the Univariate GLM and VARCOMP functions of the statistical package SPSS ${ }^{\oplus} v .19$ (IBM, Armonk, NY, USA). The statistical

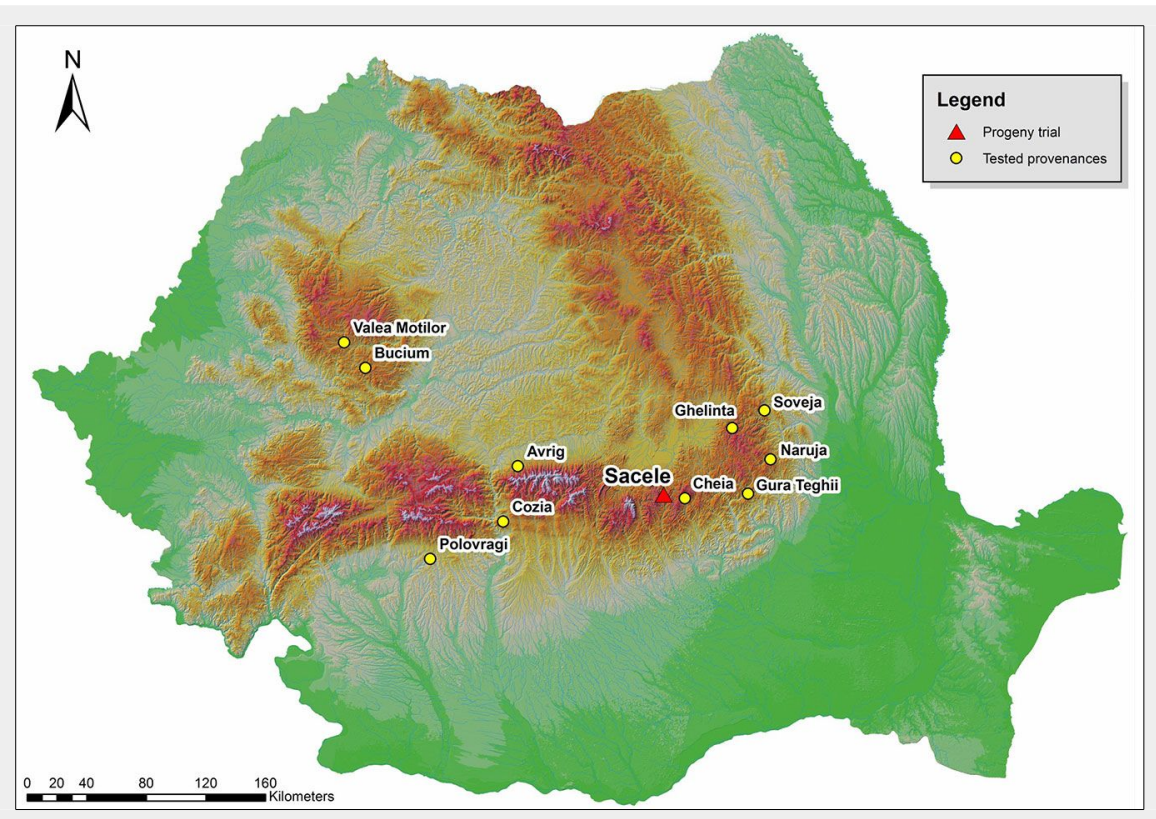

Fig. 1 - Map of Romania, location of seed sources sampled and the progeny test. analysis was based on individual tree measurements using the following linear model (eqn. 1):

$$
Y_{i j k l}=\mu+R_{i}+P_{j}+F_{k}+F R_{i k}+e_{i j k l}
$$

where $Y_{\mathrm{ijkl}}$ is the effect of the $k^{\text {th }}$ tree in the $j^{\text {th }}$ family in the $I^{\text {th }}$ provenance in the $i^{\text {th }}$ block, $\mu$ is the overall mean, $R_{\mathrm{i}}$ is the fixed effect of the $i^{\text {th }}$ block, $P_{\mathrm{j}}$ is the fixed effect of the $j^{\text {th }}$ provenance, $F_{\mathrm{k}}$ is the random effect of the $k^{\text {th }}$ family NID $\sim\left(0, \sigma_{F}^{2}\right), F R_{\text {ik }}$ is the interaction of the $k^{\text {th }}$ family and $i^{\text {th }}$ block with NID $\sim\left(0, \sigma_{\text {plot }}^{2}\right)$, and $e_{\text {ijkl }}$ is the random error associated with $\left.i j k\right|^{\text {th }}$ trees with NID $\left(0, \sigma_{e}^{2}\right)$

The assumptions of the model were checked by examining the residual plots. The family effects are assumed to be random and are associated with the average genetic effects of the open-pollinated families. We considered open-pollinated families as true half-sib families and, consequently $\sigma_{A}^{2}=4 \sigma_{F}^{2}$, where $\sigma_{A}^{2}$ is the additive genetic variance and $\sigma_{F}^{2}$ is the family variance component.

The narrow-sense individual heritability $\left(h_{\mathrm{i}}^{2}\right)$ and half-sib family mean heritability $\left(h^{2}{ }_{\mathrm{HS}}\right)$ were calculated as follows (Isik et al. 1999, Nanson 2004 - eqn. 2, eqn. 3):

$$
\begin{gathered}
h_{i}^{2}=\sigma_{A}^{2} / \sigma_{P h 1}^{2}=4 \sigma_{F}^{2} /\left(\sigma_{F}^{2}+\sigma_{p l o t}^{2}+\sigma_{w}^{2}\right) \\
h_{H S}^{2}=\sigma_{F}^{2} / \sigma_{P h 2}^{2}=\sigma_{F}^{2} /\left(\sigma_{F}^{2}+\sigma_{p l o t}^{2} / r+\sigma_{w}^{2} / r n\right)
\end{gathered}
$$

where $\sigma_{\mathrm{Ph} 1}^{2}$ and $\sigma_{\mathrm{Ph} 2}^{2}$ are the total and family mean phenotypic variances, respectively, $\sigma_{A}^{2}$ is the additive genetic variance, $\sigma_{F}^{2}$ is the family variance component, $\sigma_{\text {plot }}^{2}$ is the family $\times$ block interaction variance component, $\sigma_{w}^{2}$ is the within-plot variance, $n$ is the number of seedlings per plot, and $r$ is the number of blocks.

Standard errors of heritability were estimated according to the Dickerson's formulas (Dickerson 1969) by assuming that the denominator is a constant (eqn. 4, eqn. 5):

$$
\begin{gathered}
\operatorname{Var}\left(h_{i}^{2}\right)=16 \operatorname{Var}\left(\sigma_{F}^{2}\right) /\left(\sigma_{P h 1}^{2}\right)^{2} \\
\operatorname{Var}\left(h_{H S}^{2}\right)=\operatorname{Var}\left(\sigma_{F}^{2}\right) /\left(\sigma_{P h 2}^{2}\right)^{2}
\end{gathered}
$$

The genetic gains were calculated both at the family and individual levels for different breeding strategies (Falconer 1981). Genetic gains from mass selection $\Delta G_{1}$ (forward selection) from half-sib family selection $\Delta G_{2}$ (backward selection) were estimated as (eqn. 6 , eqn. 7 ):

$$
\begin{gathered}
\Delta G_{1}=i h_{i}^{2} \sigma_{P h 1} \\
\Delta G_{2}=i h_{H S}^{2} \sigma_{P h 2}
\end{gathered}
$$

The selection intensity $i$ was 1.996 and 1.705 for half-sib family selection (select top 5\% and $10 \%$ of families) and 1.867 and 1.638 for individual selection (select top 5\% and $10 \%$ of trees within each half-sib families - Becker 1967).

To compare the level of additive genetic 
variance in each trait independent of their means, the additive genetic coefficient of variation $(\mathrm{CV}, \%)$ was calculated as follows (Cornelius 1994 - eqn. 8):

$$
C V=\left(\sigma_{A} / \mu\right) 100
$$

where $\mu$ is the phenotypic mean of the trait.

Genetic correlations were calculated as the ratio of the covariance between traits (numerator) and the square root of the product of their additive genetic variances (denominator - Falconer \& Mackay 1996).

\section{Results}

Variance components and heritability

In general, results of the analysis of variance at different ages from previous studies reported that provenance effect was moderately significant for all the studied traits (Mihai et al. 2007, Mihai 2009). In this study, the provenance effect was not significant for the trais $\mathrm{DBH}_{34}, \mathrm{SURV}_{34}$ and LW34.

The provenances showing the highest volume growth at age 34 were Bucium, Cheia, Avrig and Naruja, while provenances Ghelinta, Gura Teghii and Soveja showed poor growth performances.

Variance components and heritability estimates are listed in Tab. 1. The results indicated that contribution of the additive genetic variance $\left(\sigma_{A}^{2}\right)$ to the total phenotypic variance $\left(\sigma_{\mathrm{Ph}}^{2}\right)$ varied between $2 \%$ for STR34 and 71\% for DRC6. Additive genetic variance is greater for stem diameter than for height in all measurement years, ranging $23-71 \%$ for stem diameter and $13-61 \%$ for height. An increasing trend of additive genetic variance with age was observed for both traits. The rate of increase was slow up to ages 10-15, and steeper at later ages.

The level of additive genetic variance of each trait was revealed by $C V \mathrm{~s}$ (Tab. 1). The $C V$ s ranged from 5 to $39 \%$, depending on the analyzed trait, and growth at early ages had higher $C V \mathrm{~s}$. Additive genetic $C V \mathrm{~s}$ displayed a decreasing trend with age for growth characters. For both total height and stem diameter, the decreasing trend was sharp up to ages 10-15 but was nearly constant thereafter. Thus, the $C V$ of the total height decreased from $25 \%$ at age 6 to $7 \%$ at age 34 , and the diameter decreased from $33 \%$ to $14 \%$ at the same age.

The narrow-sense individual heritability estimates ranged from 0.14 for $\mathrm{HT} 15$ to 0.71 for DRC6 (Tab. 1). The half-sib family heritability ranged from 0.05 for STR34 to 0.67 for DRC6. Except for DRC6, the family heritability was higher than individual heritability. Also, the heritability for overall DRC and DBH were higher compared to overall HT. Wood density, late wood, diameter and volume per tree were the silver fir traits showing the highest heritability for the entire period analyzed. A sudden decrease could be observed between 6 and 15 years both for individual and half-sib family heri-

Tab. 1 - Additive genetic variance $\left(\sigma_{\mathrm{A}}^{2}\right)$, phenotypic variance $\left(\sigma_{\mathrm{Ph}}^{2}\right)$, individual tree heritability $\left(h_{\mathrm{i}}^{2}\right)$ and family mean heritability $\left(h_{\mathrm{HS}}^{2}\right)$ and their standard errors for the stud ied traits at different ages in silver fir progeny test. The proportion (\%) of additive genetic variance out of the total phenotypic variance is given in brackets.

\begin{tabular}{lrrcrcc}
\hline Traits & Mean & CV & $\sigma^{2}{ }_{\text {A }}(\%)$ & \multicolumn{1}{c}{$\boldsymbol{\sigma}_{\text {Ph }}^{2}$} & $\boldsymbol{h}_{\text {HS }}{ }^{2}$ & $\boldsymbol{h}^{2}$ \\
\hline HT6 & 0.68 & 32 & $0.029(61)$ & 0.047 & $0.61 \pm 0.09$ & $0.61 \pm 0.09$ \\
HT10 & 1.75 & 16 & $0.083(25)$ & 0.330 & $0.47 \pm 0.20$ & $0.25 \pm 0.11$ \\
HT15 & 4.28 & 8 & $0.127(13)$ & 0.938 & $0.30 \pm 0.30$ & $0.14 \pm 0.13$ \\
HT25 & 10.03 & 6 & $0.367(17)$ & 2.204 & $0.28 \pm 0.10$ & $0.17 \pm 0.06$ \\
HT34 & 12.83 & 7 & $0.718(18)$ & 4.076 & $0.34 \pm 0.12$ & $0.18 \pm 0.06$ \\
DRC6 & 0.21 & 39 & $0.005(71)$ & 0.007 & $0.67 \pm 0.06$ & $0.71 \pm 0.06$ \\
DRC10 & 5.04 & 15 & $0.588(22)$ & 2.669 & $0.42 \pm 0.22$ & $0.22 \pm 0.12$ \\
DRC15 & 6.64 & 14 & $0.853(21)$ & 4.120 & $0.42 \pm 0.21$ & $0.21 \pm 0.11$ \\
DBH25 & 13.73 & 12 & $2.784(21)$ & 13.335 & $0.37 \pm 0.12$ & $0.21 \pm 0.07$ \\
DBH34 & 16.12 & 14 & $4.795(23)$ & 20.716 & $0.41 \pm 0.12$ & $0.23 \pm 0.07$ \\
VOL34 & 151.33 & 29 & $1.884(23)$ & 8.132 & $0.40 \pm 0.12$ & $0.23 \pm 0.07$ \\
STR34 & 1.38 & 6 & $0.007(2)$ & 0.390 & $0.05 \pm 0.08$ & $0.20 \pm 0.03$ \\
DENS34 & 0.36 & 7 & $0.001(28)$ & 0.002 & $0.40 \pm 0.24$ & $0.28 \pm 0.17$ \\
LW34 & 20.54 & 5 & $13.542(5)$ & 46.933 & $0.32 \pm 0.26$ & $0.29 \pm 0.17$ \\
SURV34 & 61.55 & 12 & $56.321(15)$ & 365.808 & $0.32 \pm 0.00$ & $0.15 \pm 0.00$ \\
\hline
\end{tabular}

tability of the growth traits. After age of 15, a stabilization of these parameters was observed.

\section{Trait-trait family mean correlations}

Family mean correlations between the studied traits are reported in Tab. 2. The parameters were calculated based on family means. Among all, those with special interest for breeding are the parameters showing significant correlation between growth traits on one hand and wood density, survival, and stem straightness on the other, or between wood density and survival. However, correlations obtained between HT34, DBH34, VOL34 and DENS34 were low and negative, with values ranging between -0.25 and -0.27 . Moreover, a negative though weak correlation between density and survival was also observed. In addtion, there were positive correlations between STR34 and both DENS34 and LW34. Correlations between wood density and the percentage of late wood were positive and high. Contrastingly, weak correlations were found between survival and the other studied traits.

\section{Age-age family mean correlations}

To determine the relationships between traits evaluated at age 34 and earlier ages, the family mean age-age correlations were estimated (Tab. 3). High age-age genetic correlations were obtained for HT, DBH

Tab. 2 - Trait-trait genetic correlations in silver fir progeny test. Wood density was negatively correlated with growth, though the correlation was weak.

\begin{tabular}{lrrrrrr}
\hline Traits & DBH34 & VOL34 & STR34 & SUPR34 & DENS34 & LW34 \\
\hline HT34 & 0.50 & 0.51 & -0.18 & 0.02 & -0.27 & -0.43 \\
DBH34 & - & 0.50 & -0.10 & 0.02 & -0.26 & -0.26 \\
VOL34 & - & - & -0.04 & 0.01 & -0.25 & -0.22 \\
STR34 & - & - & - & 0.05 & 0.45 & 0.35 \\
SUPR34 & - & - & - & - & -0.01 & -0.05 \\
DENS34 & - & - & - & - & - & 0.54 \\
\hline
\end{tabular}

and VOL, while genetic correlations for HT and $\mathrm{DBH}$ at age 34 and with age 6 were weak. As expected, HT at age 34 showed a higher correlation with the same parameter at age 25 , though correlations decreased as age difference increased. The ageage correlations between $\mathrm{VOL} 34$ and either total height or stem diameter also increased over time. The family mean ageage correlations between HT were much higher than those for stem diameter measured at the same ages. Therefore, both height and stem diameter could be considered as effective selection criteria in silver fir.

\section{Genetic gain}

The genetic gain was calculated for stem diameter and total height as the deviation (\%) from population means at age 6, 10, 15, 25 and 34 years after planting. Genetic gain varied with age, selection method, selection intensity and analyzed traits. Regardless of the selection method or age, the genetic gain was higher for stem diameter than for total height. For all traits, the estimates of genetic gain achievable through individual tree selection were greater than that attainable from half-sib family selection. The likely reason is that the selection intensity was much higher for individual trees. This is consistent with the higher genetic variation of silver fir at inter-individual level compared with inter-popula- 
Tab. 3 - Age-age additive genetic correlations from silver fir progeny test. As expected, correlations generally decreased as the difference in age increased.

\begin{tabular}{lccccccccc}
\hline Traits & HT10 & HT15 & HT25 & HT34 & DRC6 & DRC10 & DRC15 & DBH25 & DBH34 \\
\hline HT6 & 0.47 & 0.55 & 0.45 & 0.27 & 0.34 & 0.52 & 0.49 & 0.27 & 0.21 \\
HT10 & - & 0.88 & 0.71 & 0.37 & 0.45 & 0.77 & 0.76 & 0.42 & 0.34 \\
HT15 & - & - & 0.98 & 0.56 & 0.49 & 0.92 & 0.94 & 0.58 & 0.50 \\
HT25 & - & - & - & 0.68 & 0.39 & 0.75 & 0.86 & 0.80 & 0.65 \\
HT34 & - & - & - & - & 0.22 & 0.40 & 0.49 & 0.49 & 0.50 \\
DRC6 & - & - & - & - & - & 0.51 & 0.45 & 0.23 & 0.17 \\
DRC10 & - & - & - & - & - & - & 0.83 & 0.46 & 0.36 \\
DRC15 & - & - & - & - & - & - & - & 0.55 & 0.44 \\
DBH25 & - & - & - & - & - & - & - & - & 0.48 \\
\hline
\end{tabular}

Tab. 4 - Genetic gain (\%) by selection of the best $5 \%$ or $10 \%$ families and individuals within families at the age of 34 for silver fir.

\begin{tabular}{lcccc}
\hline Trait & Family $\mathbf{5 \%}$ & Family $\mathbf{1 0 \%}$ & Within $\mathbf{5 \%}$ & Within $\mathbf{1 0 \%}$ \\
\hline Height & 4 & 3 & 5 & 5 \\
Stem diameter & 9 & 7 & 12 & 11 \\
Volume & 18 & 15 & 26 & 23 \\
Stem straightness & 1 & 1 & 2 & 1 \\
Density & 5 & 4 & 7 & 6 \\
\hline
\end{tabular}

tion level, already reported in many studies (Konnert \& Bergmann 1995, Hussendörfer 1999, Longauer 2001, Teodosiu 2009).

The estimates of genetic gain at 34 years after planting for both family and individual selection are presented in Tab. 4 . If the best $5 \%$ or $10 \%$ of individuals within the halfsib families were selected, a genetic gain of $5 \%$ for $\mathrm{HT}_{34}, 12-11 \%$ for $\mathrm{DBH}_{34}$ and $26-23 \%$ for VOL34 could be achieved. The family selection at the same intensities could produce a genetic gain of $4-3 \%$ for $\mathrm{HT} 34,9-7 \%$ for $\mathrm{DBH}_{34}$ and $18-15 \%$ for VOL34. In terms of selection timing, a decrease of genetic gain after the age of 6 was observed. However, the genetic gain was quite stable between age 15 and 34 both for total height and stem diameter (Tab. 4).

The results suggested that the optimal time for early selection based on height and diameter is between 6 and 10 years after planting. Genetic gain at age 10 was $15-13 \%$ for total height and $13-12 \%$ for diameter by individual tree selection and 11-10\% for total height and 10-8\% for diameter by family selection. Although family mean correlations between wood density and growth traits were not strong, if direct selection would be done based on wood density, the estimated genetic gain would be between 4 and $7 \%$. Therefore, selection can be done at the family level, but also by selecting the best individuals within each family. Indeed, the selection of best families combined with within-family individual selection is expected to yield an increased genetic gain.

\section{Discussion}

To our knowledge, no reports on the age trends of genetic parameters for growth and quality traits in European silver fir have been published in the literature so far. Despite our results are based on a single prog- eny test established at one site, several relevant implications for silver fir breeding and forest management can be drawn from this study, as the genetic parameter assessment carried out is based on a very large number of measurements and tested families over a period of 28 years.

The moderate differences found among provenances and the highly significant differences among half-sib families are in agreement with previous studies in silver fir, which reported a high degree of variation within populations as compared with the inter-population variation (Korpel et al. 1982, Muller-Starck et al. 1992, Konnert \& Bergmann 1995, Hussendörfer 1999, Longauer 2001, Teodosiu 2009). in fact, the family effect was the most important source of variation for growth, survival and wood quality traits over the entire analyzed period. The observed family differences were small only for stem straightness.

The additive genetic variance for growth traits increased moderately from age 6 up to ages 10-15, and then increased rapidly later; consequently, the additive genetic $\mathrm{CV}$ decreased over time, becoming stable after 10 years of age for DBH and 15 years for HT.

The narrow-sense individual heritability decreased from 0.61 at age 6 to 0.14 at age 15 for HT, and from 0.71 to 0.21 for DBH at the same ages. A similar pattern was also observed for the family heritability, which decreased from 0.61 to 0.30 for HT and from 0.61 to 0.42 for DBH at age 6 and 15, respectively. At older ages, the genetic parameters for growth traits became stable over time. Such decrease in heritability could be due to the increased noise by age. Indeed, the progeny trial we analyzed has not been thinned since its establishment. As trees get older they compete for light and water availability. At 34 years of age, the diameter at breast height, volume per tree and wood density are the most heritable traits in silver fir. The heritability estimates suggest a strong genetic control for such traits and, consequently, sufficient chances of success should be ensured using the different selection methods in breeding programs.

In this study, genetic parameter estimates for growth traits were affected by age to a fairly large extent. Similar patterns of variation in genetic parameters were also observed for other species. For example, Hodge \& White (1992) and Dieters (1996) reported a high height heritability at early ages in slash pine, but a slight decline after age 10. Contrastingly, Haapanen (2001) found heritability to be fairly constant with age in Pinus silvestris L. For many tree species, juvenile-mature phase change varies according to genetic patterns with age and environmental characteristics of the traits considered. Franklin (1979) named it the "Mature Genotypic Phase", and it could explain the intensification of growth and the decline of the heritability that occurs in some conifer species. Silver fir is a species with slow growth up to $10-15$ years, and the general increasing trend of additive variance after this age may be a side effect of competition. Foster (1986) concluded that competition affects both variances and heritability. Furthermore, such changes in genetic parameters are also expected because of different genes involved in the expression of the studied traits at different ages and developmental stages (Namkoong et al. 1988).

The efficiency of early selection in breeding programs strongly depends on the genetic age-age correlation. Although we used family means to calculate trait-trait and age-age correlations, they can be considered gross estimate of genetic correlations when the number of family and their size are large enough (Lynch \& Walsh 1998). All within-family age-age average correlations for height and stem diameter were significantly different from zero, and high juvenile-mature correlations were observed for total height, diameter and volume. As expected, positive correlations were obtained between DBH and HT, while no significant correlations between survival and the other traits were observed. The correlations between growth traits and wood density were negative but statistically non-significant. These results are in accordance with those reported for other species (Haapanen et al. 1997). Therefore, height, diameter and density could probably be incorporated into a selection index.

For breeding programmes of forest tree species, assessing the trends of variance components, heritability and genetic correlations over time is crucial to optimize early selection and develop effective breeding and testing strategies (Adams \& Joyce 1990, White et al. 1993). Taking into account the variation patterns of genetic 
parameters observed in this study, the optimum time for early selection based on height and diameter is between 6 and 10 years after planting. Selection at these early ages will lead to a greater genetic gain in volume of mature silver fir trees. Regardless of age, the genetic gain is expected to be higher for $\mathrm{DBH}$ and $\mathrm{VOL}$ than for HT.

Breeding could be possible by selecting both the most valuable families and the most valuable individuals within the best families. Comparison of the genetic gain calculated by different selection strategies indicated that forward selection based on family breeding values (mid-parent breeding values) and within-family selection can be usefully combined in breeding activities.

\section{Conclusions}

The experiment reveal a large genetic variability at both the seed source and halfsib progeny levels, which can be exploited in breeding programmes and reforestation practices. The provenances showing the best growth are recommended to be designated as tested seed sources and their reproductive material to be used in artificial reforestation. Our results highlighted a high genetic control for growth and quality traits in silver fir, and a large genetic gain can be achieved on the basis of these traits. The high age-age correlation observed allows trees to be selected at early ages, and the genetic gain in mature trees can be maximized by selection on diameter and height as early as 6-10 years after planting.

\section{Acknowledgements}

This research was carried out within the GENCLIM project financed in Partnership Program by the National Authority for Scientific Research in Romania. The authors also thank the anonymous reviewers for their useful comments on earlier versions of this manuscript.

\section{References}

Adams WT, Joyce DG (1990). Comparison of selection methods for improving volume growth in young coastal Douglas fir. Silvae Genetica 39: 5-6. [online] URL: http://www.cabdirect.org/ abstracts/19911622755.html

Ballian D (2000). Intra-population and inter-population variability of some morphological and physiological characteristics of the silver fir (Abies alba Mill.) in one part of the natural range in Bosnia and Herzegovina. Annales Forestales 24 (1): 1-23.

Barzdajn W (2010). Provenance and family variation of Silver fir (Abies alba Mill.) in the experiment established in the Siemianice Forest Experimental Station in 1996. Annals of Warsaw University of Life Sciences - SGGW, Forestry and Wood Technology 73: 51-64. [online] URL: http://www.cabdirect.org/abstracts/2011308101 4.html

Becker WA (1967). Manual of procedures in quantitative genetics ( $2^{\text {nd }}$ edn). Academic Enterprise, Pullman, WA, USA, pp. 124.
Cornelius J (1994). Heritabilities and additive genetic coefficients of variation in forest trees. Canadian Journal of Forest Research 24: 372379. - doi: 10.1139/×94-050

Damian M, Leandru L (1984). Culturi comparative de proveniente la brad [Silver fir provenances comparative trials]. Redactia de propaganda tehnica agricola, Bucharest, Romania, Seria a II-a, pp. 47. [in Romanian]

Deaconu V (1991). Culturi comparative de proveniente si descendente la brad [Silver fir provenances and progeny comparative trials]. Redactia de propaganda tehnica agricola, Bucharest, Romania, Seria a II-a, pp. 55. [in Romanian]

Dean CA, Stonecypher RW (2006). Early selection of Douglas fir across south-central coastal Oregon, USA. Silvae Genetica 55 (3): 135-141. [online] URL: http://www.silvaegenetica.de/file admin/content/dokument/archiv/silvaegenetica 155_2006/55-3-135.pdf

Dickerson GE (1969). Techniques for research in quantitative animal genetics. Techniques and procedures in animal science research. American Society of Animal Science, New York, USA, pp. 36-79.

Dieters MJJ (1996). Genetic parameters for slash pine (Pinus elliotti) grown in south-east Queensland, Australia: growth, stem straightness and crown defects. Forest Genetics 3 (1): 27-36. [online] URL: http://espace.library.uq. edu.au/view/UQ:207727

Ducci $F$ (1991). Morphological variation in silver fir (Abies alba Mill.) seedlings from provenances in central and southern Italy. Annali dell'Instituto Sperimentale per la Selvicoltura (Arezzo, Italy) 22: 53-73.

Dumitriu-Tataranu I, Ghelmeziu N, Florescu I, Milea I, Mos V, Tocan M (1983). Estimarea calitatii lemnului prin metoda carotelor de sondaj [Estimation of the wood quality by wood samples]. Editura Tehnica Bucuresti, Bucarest, Romania, pp. 347. [in Romanian]

Falconer DS (1981). Introduction to quantitative genetics ( $2^{\text {nd }}$ edn). Longman and Co., New York, USA, pp. 340.

Falconer DS, Mackay TFC (1996). Introduction to quantitative genetics $\left(4^{\text {th }}\right.$ edn). Longman and Co., Harlow, NY, USA, pp. 360.

Foster GS (1986). Trends in genetic parameters with stand development and their influence on early selection for volume growth in loblolly pine. Forest Science 32: 944-959. [online] URL: http://www.ingentaconnect.com/content/saf/fs /1986/00000032/00000004/art00013

Franklin EC (1979). Model relating levels of genetic variance to stand development of four North American conifers. Silvae Genetica 28: 207-212. [online] URL: http://www.silvaegeneti ca.de/fileadmin/content/dokument/archiv/silva egenetica/28_1979/28-5-6-207.pdf

Gagov V (1985). Different origins silver fir (Abies alba Mill.) growth study in provenance trials. In: “Ergebnisse des 4. Tannen-Symposium" (Kramer $W$ ed). Schriftenreihe ausder Forstlichen Fakultat der Universitat Gottingen undder Niedersachsischen Forstlichen Versuchsanstalt 80: 278-286.

Gagov V, Evtimov I, Zhelev P (2005). Comparative study on the growth of half-sib families of selected trees of Abies alba (Mill.) and Abies borisii-regis (Mattf.) from Bulgarian and Mace- donian provenances. In: Proceedings of the $11^{\text {th }}$ International Silver Fir Symposium "Challenges for the Management of European Silver Fir (Abies alba Mill.) under Changing Climatic and Economic Conditions". Poiana Brasov (Romania) 4-9 Sep 2005. Forest Research and Management Institute, Bucharest, Romania, pp. 23. Haapanen M, Velling P, Annala ML (1997). Progeny trial estimates of genetic parameters for growth and quality traits in Scots pine. Silva Fennica 31 (1): 3-12. - doi: 10.14214/sf.a8506

Haapanen M (2001). Time trends in genetic parameter estimates and selection efficiency for Scots pine in relation to field testing method. Forest Genetics 8: 129-144.

Hansen JK, Larsen JB (2004). European silver fir (Abies alba Mill.) provenances from Calabria, southern Italy: 15-year results from Danish provenance field trials. European Journal of Forest Research 123: 127-138. - doi: 10.1007/s10342-0040031-9

Hodge GR, White TL (1992). Genetic parameter estimates for growth traits at different ages in slash pine and some implications for breeding. Silvae Genetica 41: 4-5.

Huhn M, Kleinschmit J (1993). Time trends in age-age covariances and correlations-examples from Norway spruce clones. Silvae Genetica 42 (4-5): 175-179. [online] URL: http://www.all gemeineforstundjagdzeitung.com/fileadmin/co ntent/dokument/archiv/silvaegenetica/42_1993/ 42-4-5-175.pdf

Hussendörfer E (1999). Genetic variation of silver fir populations (Abies alba Mill.) in Switzerland. Forest Genetics 6 (2): 101-113. [online] URL: http://www.tuzvo.sk/files/fg/volumes/1999/FGo 6-2_101-113.pdf

Isik F, Isik K, Lee SJ (1999). Genetic variation in Pinus brutia Ten. in Turkey: I. Growth, biomass and stem quality traits. Forest Genetics 6 (2): 89-99. [online] URL: http://silvaegenetica. com/fileadmin/content/dokument/archiv/silvae genetica/48_1999/48-6-293.pdf

Jansson G, Li B, Hannrup B (2003). Time trends in genetic parameters for height and optimum age for parental selection in Scots pine. Forest Science 49: 696-705. [online] URL: http:// www.ingentaconnect.com/content/saf/fs/2003/ 00000049/00000005/arto0005

Kerr G, Stokes V, Peace A, Jinks R (2015). Effects of provenance on the survival, growth and stem form of European silver fir (Abies alba Mill.) in Britain. European Journal of Forest Research 134: 349-363. - doi: 10.1007/s10342-0140856-9

Konnert M, Bergmann F (1995). The geographical distribution of genetic variation of silver fir in relation to its migration history. Plant Systematics and Evolution 196: 19-30. - doi: 10.1007/ BFoog85333

Korpel S, Paule L, Laffers A (1982). Genetics and breeding of the silver fir (Abies alba Mill). Annales Forestales 9 (5): 151-184.

Kranenborg KG (1994). Abies alba provenance research in the Netherlands. In: "Ergebnisse des 7. Weißtannensymposiums der WP S.1.0108" (Eder W ed). Altensteig, Germany, pp. 369381.

Longauer R (2001). Genetic variation of European silver fir (Abies alba Mill.) in the Western Carpathians. Journal of Forest Science 47: 429- 
438. [online] URL: http://agris.fao.org/agrissearch/search.do?recordID=CZ2001001241 Lynch M, Walsh B (1998). Genetics and analysis of quantitative traits. Sinauer Associates, Sunderland, MA, USA, pp. 980.

Mayer M, Reimoser E, Kral F (1980). Results of the international fir provenance trial, Wien, 1967/78. Growth and morphology of the provenances. Centralblat fur das gesamte Fortswesen 99: 169-191.

Mihai G, Stuparu E, Scarlatescu V, Vlasin H (2007). Genetic variation and breeding of silver fir in Romania. Analele ICAS 50: 27-44.

Mihai G (2009). Surse de seminte testate pentru principalele specii de arbori forestieri din Romania [Tested seed sources for the main forest species in Romania] (Mihai $G$ ed). Editura Silvica, Bucharest, Romania, pp. 280. [in Romanian]

Mihai G, Mirancea I, Duta C (2014). Variation of the quantitative traits in a progeny test of Abies alba (Mill.) at the nursery stage. Silvae Genetica 63 (6): 275-284.

Muller-Starck G, Baradat P, Bergmann F (1992). Genetic variation within European tree species. Kluwer Academic Publisher, Frankfurt am Main, Germany, pp. 23-47. - doi: 10.1007/BF00120638

Namkoong G (1979). Introduction to quantitative genetics in forestry. Technical Bulletin 1588, USDA Forest Service, Washington, DC, USA, pp. 342. [online] URL: http://books.google.com/ books?id=xrcoAAAAYAAJ

Namkoong G, Kang HC, Brouard JS (1988). Tree breeding: principles and strategies. SpringerVerlag, New York, USA, pp. 180.

Nanson A (2004). Genetique et amelioration des arbres forestieres [Genetics and forest tree improvement]. Les Presses Agronomique, Gembloux, Belgium, pp.712. [in French]

NFI (2012). National Forest Inventory 2012. Web site. [online] URL: http://roifn.ro/site/en/

Stackpole DJ, Vaillancourt RE, Aguigar M, Potts BM (2010). Age trends in genetic parameters for growth and wood density in Eucalyptus globulus. Tree Genetics and Genomes 6: 179193. - doi: 10.1007/s11295-009-0239-4

Stoehr M, Yanchuk A, Xie CY, Sanchez L (2008). Gain and diversity in advanced-generation coastal Douglas fir selections for seed production populations. Tree Genetics and Genomes 4: 193-200. - doi: 10.1007/s11295-007-0100-6 Svensson JC, McKeand SE, Allen HL, Campbell RG (1999). Genetic variation in height and volume of loblolly pine open-pollinated families during canopy closure. Silvae Genetica 48: 204208. [online] URL: http://www.rheinischesmu seumfuerphilologie.de/fileadmin/content/doku ment/archiv/silvaegenetica/48_1999/48-3-4-20 4.pdf

Teodosiu M (2009). Evaluating the genetic diversity of silver fir by isozyme gene markers. In: "Tested seed sources for the main forest species in Romania" (Mihai G ed). Editura Silvica, Bucharest, Romania, pp. 178-184. [in Romanian]

White TL, Hodge GR, Powell GL (1993). An ad- vanced-generation tree-improvement plan for slash pine in the south-eastern United States. Silvae Genetica 42 (6): 359-370. [online] URL: http://www.rheinischesmuseumfuerphilologie. de/fileadmin/content/dokument/archiv/silvaege netica/42_1993/42-6-359.pdf

Wolf H (1994). Silver fir provenances: recent results related to provenance research of Abies alba Mill. (Wolf $\mathrm{H}$ ed). Ecomed-Verlag, Landsberg am Lech, Germany, pp. 150. [online] URL: http://www.cabdirect.org/abstracts/199506168 31.html

Ye TZ, Jayawickrama KJS (2012). Early selection for improving volume growth in coastal Douglas fir breeding programs. Silvae Genetica 61: 4-5. [online] URL: http://ir.library.oregonstate. edu/xmlui/handle/1957/38172

Zobel BJ, Talbert J (1984). Applied forest tree improvement. John Wiley and Sons, New York, USA, pp. 505. [online] URL: http://www.cab direct.org/abstracts/19840699048.html

Zobel BJ, Jett JB (1995). Genetics of wood production. Springer Series in Wood Science, Heidelberg, Germany, pp. 337.

\section{Supplementary Material}

Tab. S1 - Results of the analysis of variance for the traits considered.

Link: Mihai_1766@supploo1.pdf 